\title{
Regression of syringomyelia and tonsillar herniation after posterior fossa arachnoid cyst excision. Case report and literature review
}

\author{
J. F. Martínez-Lage; M.J. Almagro; J. Ros de San Pedro; A. Ruiz-Espejo and M. Felipe-Murcia
}

Servicio Regional de Neurocirugía. Hospital Universitario Virgen de la Arrixaca. El Palmar. Murcia.

Summary

Background. Some reports have documented posterior fossa cysts resulting in syringomyelic obstruction of cerebrospinal fluid (CSF) flow caused by cyst displacement within the foramen magnum. Rarely the syringomyelia is caused by acquired Chiari malformation due to a retrocerebellar arachnoid cyst.

Objective. To report the case of a 38-year-old man with hydrocephalus and syringomyelia, who was found to have a Chiari malformation secondary to a posterior fossa arachnoid cyst. After endoscopic third ventriculostomy, the patient was submitted to foramen magnum decompression and arachnoid cyst removal that were followed by resolution of both the Chiari malformation and the syringomyelia.

Discussion. In most published cases the syringomyelia has been attributed to obstruction of CSF flow at the foramen magnum by the arachnoid cyst itself. There is only one previous report of a posterior fossa arachnoid cyst producing tonsillar descent and syringomyelia.

Conclusions. Posterior fossa arachnoid cysts can result in acquired Chiari malformation and syringomyelia. In our view, the management of these patients should be directed at decompressing the foramen magnum and include the removal of the walls of the coexistent arachnoid cyst as it seems to be the crucial factor that accounts for the development of the syringomyelia that these patients present.

KEYWORDS: Acquired Chiari malformation. Syringomyelia. Arachnoid cyst. Foramen magnum decompression. Endoscopic third ventriculostomy.

Resolución de siringomielia y herniación de las amígdalas cerebelosas tras la escisión de un quiste aracnoideo de fosa posterior. Descripción de un caso y revisión de la literatura
Resumen

Antecedentes. Algunos trabajos han descrito la existencia de quistes aracnoideos de fosa posterior que producían siringomielia al obstruir la circulación de liquido cefalorraquídeo (LCR) por bloqueo del agujero magno ocasionado por el propio quiste. Rara vez la siringomielia asociada a quiste aracnoideo de fosa posterior es producida por malformación de Chiari adquirida.

Objetivos. Publicar el caso de un hombre de 38 años con hidrocefalia y siringomielia, en el que se encontró descenso de las amígdalas cerebelosas por la presión ejercida por un quiste aracnoideo retrocerebeloso. Tras tratar primero la hidrocefalia mediante ventriculostomía neuroendoscópica, el paciente fue operado de descompresión del agujero magno y extirpación de las membranas del quiste que condujeron a la resolución tanto del Chiari como de la siringomielia.

Discusión. En la mayoría de los casos publicados la siringomielia se debía a la obstrucción de LCR en el agujero magno ocasionada por el propio quiste aracnoideo. Hemos encontrado solamente un caso previo en el que el quiste de fosa posterior era causante del descenso de las amígdalas cerebelosas y éste, a su vez, producía la siringomielia.

Conclusiones. Los quistes aracnoideos de fosa posterior pueden producir descenso de las amígdalas y siringomielia. En nuestra opinión, el manejo de estos pacientes debe de encaminarse no sólo a descomprimir el agujero magno, sino también a comunicar las paredes del quiste ya que éste parece ser el principal responsable del complejo cuadro de siringomielia en estos casos.

PALABRAS CLAVE: Malformación de Chiari adquirida. Siringomielia. Quiste aracnoideo. Descompresion del agujero magno. Ventriculostomía neuroendoscópica.

Recibido: 12-02-06. Aceptado: 24-02-06 


\section{Introduction}

Arachnoid cysts are benign collections of cerebrospinal fluid (CSF) that develop as the result of an abnormal duplication of the arachnoid membranes during brain development. Arachnoid cysts account for approximately $1 \%$ of all intracranial mass lesions. Posterior fossa arachnoid cysts roughly represent one fourth of all these congenital pouches. There have been several reports of large arachnoid cysts associated with syringomyelia ${ }^{2-8,10,12-14}$. These patients have been managed with a variety of procedures including foramen magnum decompression, with or without cyst removal, cysto-peritoneal shunting or endoscopic cyst fenestration ${ }^{2-}$ $8,10,12-14$. In the majority of these cases, the development of syringomyelia has been related to the obstruction of CSF flow caused by the downward invagination of the cyst itself within the foramen magnum. A different mechanism has been put forward by Bauer et al. who reported a case of a posterior fossa cyst with syringomyelia secondary to tonsillar herniation caused by the push exerted by a retrocerebellar arachnoid cyst $t^{4}$. From current literature, it becomes obvious that patients with syringomyelia or Chiari malformation must be managed in an individualized manner taking into account the pathogenetic factors involved in their development ${ }^{1,11}$.

In the present work, the authors report what they believe represents the second case of a patient with syringomyelia and acquired Chiari malformation due to a retrocerebellar cyst, review the current literature, and propose to perform foramen magnum decompression together with cyst wall excision as the treatment of choice for these complex cases.

\section{Case report}

A 38-year-old man was first seen because of headaches, right arm weakness and insensibility to pain and temperature on his right hand. He also referred having had 3 episodes of drop attack. On physical examination the patient was fully conscious and had a bilateral $6^{\text {th }}$ cranial nerve paresis and loss of hearing on the left side. Motor power and ability were diminished on his upper extremity but there was no atrophy. Deep reflexes could not be elicited on the right arm. There was also dissociated hypoesthesia on his right arm and shoulder. The rest of the examination was unremarkable. Magnetic resonance imaging (MRI) showed a retrocerebellar arachnoid cyst, descent of the cerebellar tonsils and a syringomyelic cavity extending from $\mathrm{C} 2$ to $\mathrm{T} 6$ (Fig. 1 a and 1 b). Computerized tomography cerebral scan disclosed the presence of hydrocephalus.

On 3 August 2004, an endoscopic third ventriculostomy was performed, after which the headaches markedly improved. Neuroimaging studies showed no changes in his posterior fossa cyst, cerebellar tonsil's location or syringomyelia. Clinically, the patient's condition seemed to be deteriora-
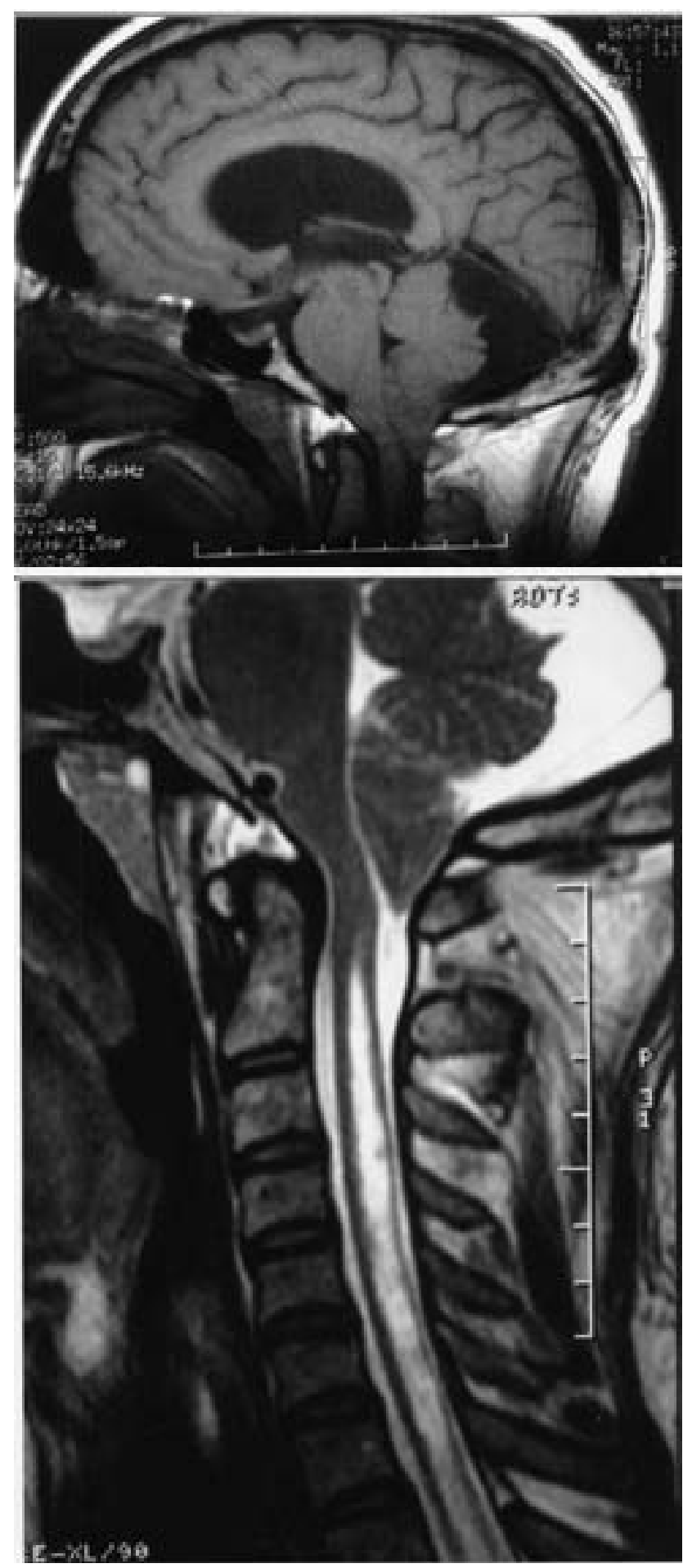

Figure 1. Preoperative MRI study of the patient showing: (a) acquired tonsillar herniation and a voluminous retrocerebellar arachnoid cyst, and (b) the syringomyelic cavity.

ting. On 4 April, 2005 the patient underwent suboccipital craniectomy and $\mathrm{Cl}$ laminectomy with ample removal of the arachnoid cyst's walls. The dura mater was closed with 
a dural graft. Histopathological study of the excised tissues showed flattened cells of meningothelial origin on a loose fibrous wall with normal vessels.

The patient made an uneventful recovery, and at 10month follow-up visit he manifested to have gained some strength on his right hand, although the objective neurological examination remained unchanged. However, a MRI control showed normalization of the cerebellar tonsils' position and a significant shrinkage of the cervicothoracic syringomyelic cavity (Fig. 2 a and b)

\section{Discussion}

The most frequent reported cause of cerebellar tonsil herniation is the Chiari type 1 congenital malformation. This anomaly is one of the four types of hindbrain malformations described by Hans Chiari in $1891^{1,11}$. Chiari Type I malformation is often described as the caudal displacement of the cerebellar tonsils below the level of the foramen magnum with or without syringomyeliaa ${ }^{1,11}$. Several theories have been proposed to explain both the tonsillar descent and the frequently associated syringomyelia ${ }^{11}$. According to Gardner's theory the primary event consists of an imperforation of the rhombic roof, the supratentorial raised intracranial pressure displaces the tentorium and a shallow posterior fossa develops ${ }^{11}$. Evidence supports the hypothesis that the main problem in the Chiari I malformation is a posterior cranial fossa of smaller than normal volume ${ }^{11}$. The posterior fossa originates by endochondral ossification of the cartilaginous scaffold that forms the cranial base as well as the first four somites that model the occipital bone ${ }^{4,9}$. Marin-Padilla and Marin Padilla attributed the development of the Chiari malformation to a primary defect in the development of the basicranium $^{9}$. The production of syringomyelia in the context of the Chiari type 1 malformation has been amply reviewed and is beyond the scope of our study ${ }^{1,11}$. In a recent study, based on dynamic-MRI studies, Oldfield et al. ${ }^{11}$ propose that the descended tonsils obstruct the CSF flow to and from the spinal compartment at the foramen magnum thus explaining the appearance of syringomyelia.

The so-called "acquired" Chiari malformation seems to be better characterized ${ }^{1}$. In these cases there exists a pressure gradient across the cranial and spinal compartments, due either to increased intracranial pressure, as happens in supratentorial masses or hydrocephalus, or to CSF diversion into the spinal compartment. Several publications have documented the denovo appearance of tonsillar herniation in a variety of conditions including supra e infratentorial brain tumors, pseudotumor cerebri, craniosynostosis, cranio-encephalic disproportion, or overdrainage of $\mathrm{CSF}^{1}$.

Most cases of Chiari 1 malformation will present with clinical manifestations of posterior fossa/foramen magnum compression (head and neck pain, cerebellar signs, cranial
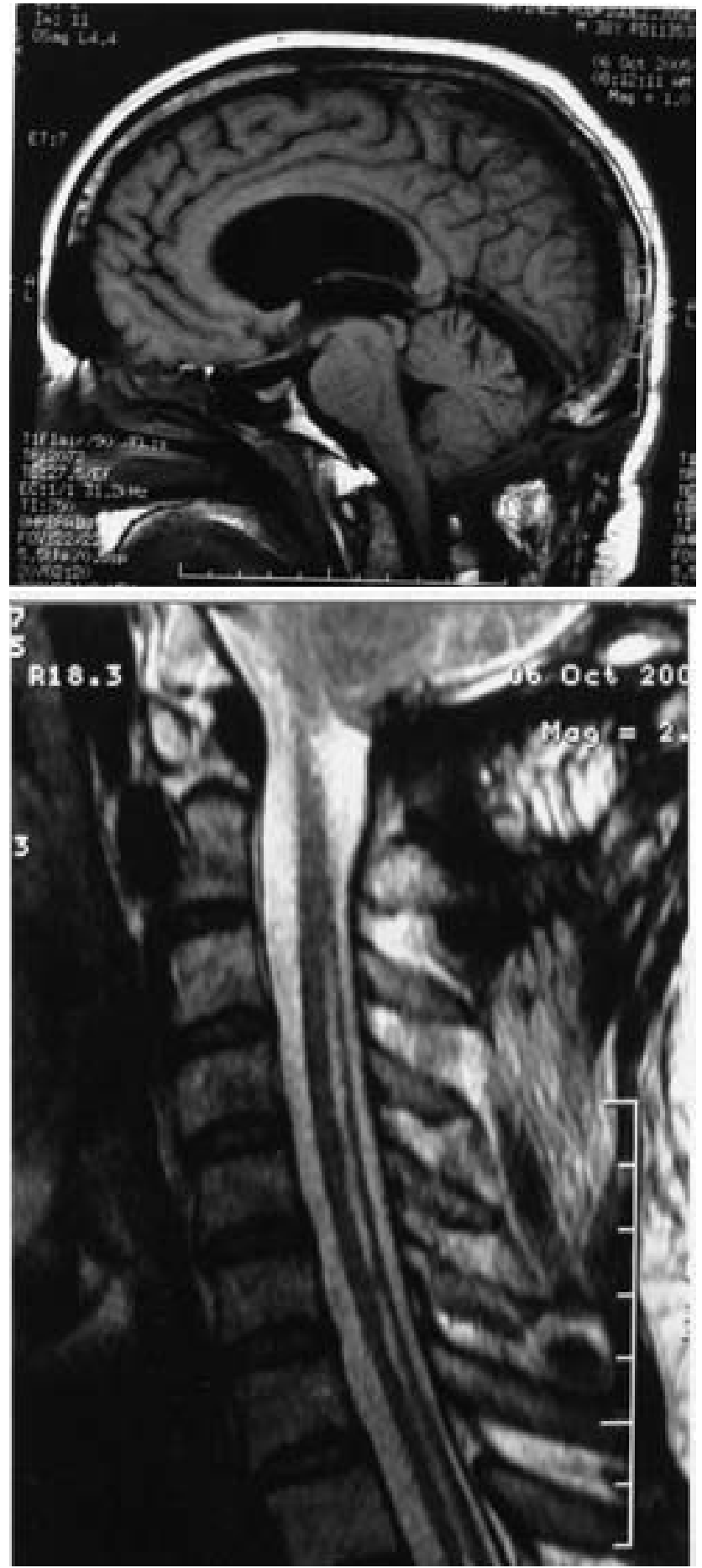

Figure 2. MRI performed 10 months after posterior fossa decompression and cyst excision illustrating (a) reduction in the size of the arachnoid cyst and normal intracranial position of the cerebellar tonsils, and (b) marked shrinkage of the intramedullary cavity.

nerve dysfunction, dysphagia, sleep apnea, and respiratory difficulty) or of spinal cord involvement (dysesthesiae, 
Table

Literature review of syringomyelia in patients with posterior fossa arachnoid cysts

\begin{tabular}{|c|c|c|c|c|}
\hline $\begin{array}{l}\text { Author, } \\
\text { Year }\end{array}$ & $\begin{array}{l}\text { Age, } \\
\text { Sex }\end{array}$ & Findings & $\begin{array}{c}\text { Tonsillar } \\
\text { descent }\end{array}$ & Treatment \\
\hline \multirow[t]{3}{*}{$\begin{array}{l}\text { Banna, } \\
1988\end{array}$} & $\begin{array}{l}6 \\
F\end{array}$ & PF arachnoid cyst, hydromyelia & no & $\begin{array}{l}\text { FM decompression \& cyst } \\
\text { excision }\end{array}$ \\
\hline & $\begin{array}{l}14 \\
\mathrm{M}\end{array}$ & hydrocephalus, PF arachnoid cyst, hydromyelia & no & $\begin{array}{l}\text { FM decompression \& cyst } \\
\text { excision, myelotomy }\end{array}$ \\
\hline & $\begin{array}{l}2 \\
\mathrm{M}\end{array}$ & hydrocephalus, DW cyst, syringomyelia & no & VP shunt, cystoperitoneal shunt \\
\hline $\begin{array}{l}\text { Zager et al } \\
1990\end{array}$ & $\begin{array}{l}9, \\
F\end{array}$ & hydrocephalus, arachnoid cyst, syringomyelia & no & $\begin{array}{l}\text { VA shunt, laminectomy and FM } \\
\text { decompression }\end{array}$ \\
\hline $\begin{array}{l}\text { Cano et al, } \\
1993\end{array}$ & $\begin{array}{r}47 \\
F\end{array}$ & $\mathrm{PF}$ arachnoid cyst, syringomyelia & no & cystoperitoneal shunting \\
\hline \multirow[t]{2}{*}{$\begin{array}{l}\text { Tokime et al, } \\
1997\end{array}$} & $\begin{array}{r}14 \\
F\end{array}$ & hydrocephalus, PF arachnoid cyst, syringomyelia & no & cystoperitoneal shunt \\
\hline & $\begin{array}{l}7 \\
\mathrm{M}\end{array}$ & $\mathrm{PF}$ arachnoid cyst, syringomyelia & & cystoperitoneal shunt \\
\hline \multirow[t]{2}{*}{$\begin{array}{l}\text { Arunkumar } \\
\text { et al, } 1998\end{array}$} & $\begin{array}{c}15, \\
F\end{array}$ & hydrocephalus, PF arachnoid cyst, syringomyelia & no & $\begin{array}{l}\text { FM decompression \& cyst } \\
\text { opening }\end{array}$ \\
\hline & $\begin{array}{l}39 \\
\mathrm{M}\end{array}$ & hydrocephalus, PF arachnoid cyst, syringomyelia & no & $\begin{array}{l}\text { FM decompression \& cyst } \\
\text { opening }\end{array}$ \\
\hline $\begin{array}{l}\text { Jain et al, } \\
2000\end{array}$ & $\begin{array}{r}14, \\
F\end{array}$ & hydrocephalus, PF arachnoid cyst, syringomyelia & no & $\begin{array}{l}\text { FM decompression and cyst } \\
\text { excision }\end{array}$ \\
\hline $\begin{array}{l}\text { Nomura } \\
\text { et al, } 2002\end{array}$ & $\begin{array}{c}32 \\
\mathrm{M}\end{array}$ & $\mathrm{PF}$ arachnoid cyst, syringomyelia & no & $\begin{array}{l}\text { neuroendoscopic cyst } \\
\text { fenestration }\end{array}$ \\
\hline $\begin{array}{l}\text { Conti et al, } \\
2003\end{array}$ & $\begin{array}{c}37, \\
\mathrm{~F}\end{array}$ & $\begin{array}{l}\text { hydrocephalus, Blake's pouch cyst, } \\
\text { syringomyelia }\end{array}$ & no & FM decompression, VP shunt \\
\hline $\begin{array}{l}\text { Lee et al, } \\
2004\end{array}$ & $\begin{array}{l}32 \\
\mathrm{M}\end{array}$ & $\begin{array}{l}\text { posttraumatic hydrocephalus, PF arachnoid cyst, } \\
\text { syringomyelia }\end{array}$ & no & VP Shunt \\
\hline $\begin{array}{l}\text { Owler et al, } \\
2004\end{array}$ & $\begin{array}{r}29 \\
M\end{array}$ & hydrocephalus, DW, syringomyelia & no & FM decompression \\
\hline $\begin{array}{l}\text { Bauer et al, } \\
2005\end{array}$ & $\begin{array}{c}38, \\
F\end{array}$ & $\begin{array}{l}\text { achondroplasia, PF arachnoid cyst, Chiari, } \\
\text { syringomyelia }\end{array}$ & yes & $\begin{array}{l}\text { FM decompression \& cyst } \\
\text { opening }\end{array}$ \\
\hline Present study & $\begin{array}{c}38 \\
\mathrm{M}\end{array}$ & hydrocephalus, PF arachnoid cyst, syringomyelia & yes & $\begin{array}{l}\text { ETV, FM decompression \& cyst } \\
\text { removal }\end{array}$ \\
\hline
\end{tabular}

$\mathrm{F}=$ female. $\mathrm{M}=$ male. $\mathrm{DW}=$ Dandy-Walker. $\mathrm{ETV}=$ endoscopic third ventriculostomy. $\mathrm{FM}=$ foramen magnum. $\mathrm{PF}=$ posterior fossa. $\mathrm{VA}=$ ventriculoatrial. $\mathrm{VP}=$ ventriculoperitoneal. 
dissociated sensory loss, loss of fine movements, sensory level, spasticity, scoliosis or sphincteric disturbances).'

In our literature review, we found 15 cases of syringomyelia accompanying diverse cystic processes of the posterior cranial fossa, such as congenital arachnoid cysts, Dandy-Walker malformation, Blake's pouch cyst, and posttraumatic CSF pouches, which are summarized in the Table ${ }^{2-8,10,12-14}$. In 14 instances the obstruction to the normal flow of CSF through the foramen magnum was due to blockage by the walls of the cyst itself. In all these cases, there was a coexistent syringomyeliaa $2,3,5-8,10,12-14$. Ten patients had hydrocephalus of diverse severity that would contribute to the formation of the hydromyelic cavity. Those cases were managed with a variety of procedures aimed at addressing the underlying pathogenetic mechanism, and included ventriculo- and cysto-peritoneal shunting, endoscopic fenestration, or direct approach to the cyst by foramen magnum decompression and cyst opening or excision.

The case reported by Bauer et al. ${ }^{4}$ is similar to that of our patient in that the obstacle to CSF circulation through the foramen magnum was due to acquired Chiari malformation that, in turn, seemed to originate from the cerebellar displacement exerted by the push of the retrocerebellar arachnoid cyst. Although hydrocephalus was a contributing factor, the Chiari malformation and the syringomyelic cavity in our case must be the consequence of the pressure exerted by the retrocerebellar cyst, as demonstrated by the resolution of the tonsillar descent and the syringomyelia following osseous decompression and surgical excision of the cyst walls. As in other instances of hydrocephalus-associated syringomyelia, the initial treatment for hydrocephalus in our patient was aimed at alleviating the raised intracranial pressure to prevent the risk of acute cerebellar herniation that can occur during the posterior fossa procedure. The second operation comprised foramen magnum decompression and ample fenestration of the cyst walls that lead to the resolution of both the tonsillar descent and the syringomyelia.

\section{Conclusions}

We have reported the second case of the successful management of syringomyelia associated to acquired Chiari malformation secondary to a retrocerebellar arachnoid cyst. We have briefly reviewed cases of syringomyelia associated with posterior fossa cysts. As in other instances of syringomyelia, we recommend to address the surgical management in accordance with the hypothetical underlying mechanism.

\section{References}

1. Alden, T.D., Ojemann, J.G., Park, T.S.: Surgical treatment of Chiari I malformation: indication and approaches. Neurosurg Focus 2001;11 (1) article 2.
2. Arunkumar, M.J., Korah, I., Chandy, M.J.: Dynamic CSF flow study in the pathophysiology of syringomyelia associated with arachnoid cysts of the posterior fossa. $\mathrm{Br} \mathrm{J}$ Neurosurg 1998; 12: 33-36.

3. Banna, M.: Syringomyelia in association with posterior fossa cysts. AJNR 1988; 9: 86-873.

4. Bauer, A.M., Mueller D.M., Oró, J.J.: Arachnoid cyst resulting in tonsillar herniation and syringomyelia in a patient with achondroplasia. Case report. Neurosurg Focus 2005; 19 (5) E14.

5. Cano, G., Anderson, M., Kutschbach, P., Borden, J., Saris, S.: Hydromyelia associated with posterior fossa cyst. Surg Neurol 1993; 40: 512-515.

6. Conti, C., Lunardi, P., Buzzao, A, Liccardo, G., Fraioli, B.: Syringomyelia associated with hydrocephalus and Blake's pouch cyst. Spine 2003; 28: E-279-E283.

7. Jain, R., Sawlani, V., Phadke, R, Kumar, R.: Retrocerebellar arachnoid cyst with syringomyelia: a case report. Neurol India 2000; 48: 81-83.

8. Lee, E.J., Yoon, S.H., Cho, K.H., Sim, S.Y.: Syringomyelia as a sequelae of the $4^{\text {th }}$ ventricular dilatation from traumatic hydrocephalus and cerebellar atrophy. J Korean Neurosurg Soc 2004; 36: 242-245.

9. Marín-Padilla, M., Marin-Padilla, T.M.: Morphogenesis of experimentally induced Arnold-Chiari malformation. J Neurol Sci 1981; 50: 29-55.

10. Nomura, S., Akimura, T., Imoto, H., Nishizaki, T., Suzuki, M.: Endoscopic fenestration of posterior fossa arachnoid cyst for the treatment of presyrinx myelopathy. Case report. Neurol Med Chir (Tokyo) 2002: 42: 452-454.

11. Oldfield, E.H., Muraszko, K., Shawker, T.H., Patronas, N.J.: Pathophisiology of syringomyelia associated with Chiari I malformation of the cerebellar tonsils. Implications for diagnosis and treatment. J Neurosurg 1994; 80: 3-15.

12. Owler, B.K., Halmagyi, G.M., Brennan, J., Besser, M.: Syringomyelia with Chiari malformation: 3 unusual cases with implications for pathogenesis. Acta Neurochir (Wien) $2004 ; 146 ; 1137-1143$.

13. Tokime, T., Okamoto, S., Yamagata, S., Konishi, T.: Syringomyelia associated with a posterior fossa cyst. Illustration of two cases. J Neurosurg 1997; 86:907.

14. Zager, E.L., Ojemann, R.G., Poletti, C.E.: Acute presentation of syringomyelia. Report of three cases. J Neurosurg 1990; 72: 133-138.

Martínez-Lage, J.F.; Almagro, M.J.; Ros de San Pedro, J.;. Ruiz-Espejo, A.; Felipe-Murcia, M.: Regression of syringomyelia and tonsillar herniation after posterior fossa arachnoid cyst excision. Case report and literature review. Neurocirugía 2007; 18: 227-231.

Correspondencia postal: Juan F. Martínez-Lage. Servicio Regional de Neurocirugía. Hospital Universitario Virgen de la Arrixaca. 30120 El Palmar, Murcia. Spain 